\title{
SPECIAL OR INCLUSIVE EDUCATION IN ROMANIA?
}

\author{
Teodor Mircea ALEXIU, Associate Professor, Phd $^{1}$ \\ Elena-Loreni BACIU, Assistant Professor, Phd ${ }^{2}$ \\ Johans Tveit SANDVIN, Professor, Phd $^{3}$ \\ Andreea Georgiana BIRNEANU, Assistant Lecturer, Phd ${ }^{4}$ \\ ${ }^{1}$ West University of Timişoara, Romania \\ ${ }^{2}$ West University of Timişoara, Romania \\ ${ }^{3}$ University of Nord, Bodo, NordlandRegion, Norway \\ ${ }^{4}$ West University of Timişoara, Romania
}

\section{(C) 2016 Teodor Mircea Alexiu, Elena-Loreni Baciu, Johans Tveit Sandvin, Andreea Georgiana Birneanu}

This is an open access article distributed under the Creative Commons Attribution-NonCommercial-NoDerivs license (http://creativecommons.org/licenses/by-nc-nd/3.0/)

DOI: 10.1515/eras-2016-0007

\begin{abstract}
In our paper we will try to explore the process of reforming the "special needs education" ideology of the Romanian school system toward the European target called "inclusive education". Following the method of inquiry named Institutional Ethnography, our study investigated first the everyday dysfunctional experiences of special needs populations approaching the scholar system, and then the institutional response for these dysfunctionalities, the final target being a better understanding and finding solutions to the problematics encountered.

After the dissolution of the communist regime very few disabled students succeeded to be integrated in the general education and these happy cases happened in the prestige schools with dedicated teachers and mainly because of the huge efforts of the parents. The most part of the disabled students had to address the old special schools (much less organized and financed than they used to be) to get vocational training for the special protected units that disappeared in the meantime.

An inclusive school would be fit for an inclusive society but when the labour market and society as a whole is excluding this category, the segregated education seem the proper approach and illustrate the reproductive efforts of the society through the education in the Bourdieu perspective.

In fact the "inclusive education" European model seems still far for Romania. Even the objective is clear the path is still unclear, due the discriminatory resistance of the society. A learning process is needed but the process seems difficult because "students" refuse to learn it and teachers seem very hard to find.
\end{abstract}

.Keywords: Special education, Inclusive education, Social inclusion.

\section{Introduction}

Romania is fighting since about 200 years, when modern times came upon us, to integrate in the international streams of civilization, to be part of the modern world. The process involved the unification of the national territory, obtaining the state independence and building a modern constitution but also starting a never ending string of reforms. The rhythm more and more accelerated of these reforms brought along the dilemma between tradition and modernity. Or,putted in other terms: should we leave our national and traditional ways of doing and believing for these new and civilized world wide accepted models of doing and believing? By doing so, are we not in danger of losing our true identity and reforming our society toward some "forms without a content" as used to worry remarkable Romanian 
intellectuals at the end of the $19^{\text {th }}$ century.

In the most recent part of our history, Romania succeeded to become a member of the European Union and since 2007 we have to accept and apply the values, norms and attitudes regulated by this international organization. By doing so we have to reform the functioning of many sectors of our society and the old dilemma reappears periodically, grouping the citizens in partisans and contesters of the European innovative requirements.

In our text below we will try to explore the process of reforming the "special needs education" ideology of the Romanian school system toward the European target called "inclusive education". The research leading to the following results has received funding from EEA Financial Mechanism 2004-2014 under the project EQUALimplemented by the West University of Timişoara, Romania in partnership with the Nord University, Bodø, Norway. Following the method of inquiry named Institutional Ethnography, our study investigated first the everyday dysfunctional experiences of vulnerable populations approaching the scholar system, and then the institutional response for these dysfunctionalities, the final target being a better understanding and finding solutions to the problematics encountered.

\section{World and European perspectives}

Education is a decisive domain in preparing the young students for the future life in the society. It offers the main abilities for a future profession, provides social skills for human interrelations, and offers the social and political tools for adapting to the community life and for developing the society. It offers knowledge and understanding and the education system can be described, in Pierre Bourdieu's terms (Bourdieu,Pierre Jean Claude Passeron, (1990), as a «reproduction tool» used by the society to assure its continuity.

As Fink (2008) observes: "Education is more than preparing students to make a living, although that is important. It is also about preparing them to make a life".

In this perspective, the barriers in the admission of the disabled students in the mainstream education, means not only to refuse them the common integration in a fundamental social institution, excluding and segregating this category from the start from their normal social inclusion process. It means also depriving these youngsters from a fundamental citizen's rights, the constitutional right to participate in the educational system on a geographical base as any other young student of the same age.

At European Union (EU) level, Article 26 of the Charter of Fundamental Rights of the European Union provides a guiding principle for EU legislative and policy measures to support full inclusion of children with disabilities. This is reflected in the European Disability Strategy 2010-2020, which clearly supports the inclusion of children with disabilities into mainstream education. Furthermore, it commits the EU to support, through the Education and Training 2020 programme the member states efforts to remove legal and organisational barriers to people with disabilities entering the general education and lifelong learning systems and to guarantee them inclusive education and personalised training at all levels of education. It sets out four strategic objectives for education and training in the EU: making lifelong learning and mobility a reality; improving the quality and efficiency of education and training; promoting equality, social cohesion and active citizenship; and enhancing creativity and innovation (including entrepreneurship) at all levels of education and training.

For this the Salamanca Statement (UNESCO, 1994) regarding inclusive education has been the guiding principle: 'Regular schools with this inclusive orientation are the most effective means of combating discriminatory attitudes, creating welcoming communities, building an inclusive society and achieving education for all; moreover, they provide an effective education to the majority of children and improve the efficiency and ultimately the 
cost-effectiveness of the entire education system.' (p.8)

The report on the Agency's Raising Achievement for All Learners (RA4AL) conference (2011) highlights that topics around the definition of inclusion became increasingly important, but that there appears to be growing agreement on the need for a rights-based approach to develop greater equity and social justice and to support the development of a non-discriminatory society. The debate about inclusion has, therefore, broadened from one that used to focus on relocating children described as having special educational needs into mainstream schools, to one that seeks to provide high-quality education - and consequent benefits - for all learners. As more countries move to a wider definition of inclusive education, diversity is recognized as 'natural' in any group of learners and inclusive education can be seen as a means of raising achievement through the presence (access to education), participation (quality of the learning experience) and achievement (learning processes and outcomes) of all learners.

Challenging the idea that including all learners may somehow be detrimental to high achievement, the OECD (2011) shows that improving the lowest performing students does not have to be at the expense of higher performers. The findings of the UNESCO report Learning Divides (2012) also provide evidence that strong school performance and equity can go hand-in-hand and that countries with the highest levels of performance tend to be those that are successfully raising the achievement of all learners.

Several studies outline the benefits of inclusion for learners without disabilities. These benefits include: increased appreciation and acceptance of individual differences and diversity, respect for all people, preparation for adult life in an inclusive society and opportunities to master activities by practising and teaching others. Such effects are also documented in recent research, for example Bennett and Gallagher (2012).

And finally about the financing issues here is a quote from a participant from a special hearing at the European Parliament in Brussels (2012) with 88 young people, both with and without special educational needs and/or disabilities, from secondary and vocational education,: Inclusive education is quite often claimed to be expensive, but in trying to save, we end up paying more to handle problems anyway. ... Even if a country doesn't have many resources, inclusive education needs to be done in the best way. Inclusive education is an investment, we must invest in people; people are the only resource"

\section{Barriers in admission of the disabled students in mainstream schools from Romania (at all levels). Where are they coming from?}

In a previous phase of our study, we collected many testimonies from disabled people about the barriers encountered in their access to regular educational institutions at all levels (primary, secondary and higher education). A para-paresis interviewee is remembering her first grade admission difficulties: "I had to pass many tests of 5 hours, intelligence quotient, almost 2 years after that I got in although...um.... Well, I wanted to be closer, [to be accepted] by the Middle School no. 2 or Middle School no. 9, but they didn't accept me. (Why?) Because I had a disability. Then another way was found. (Was that the reason why they didn't accept you?) Yes. No teacher would want me. (How old were you then?) 9 years old. Meaning I was 2 years [older]... (And you'd go to be accepted in the $1^{\text {st }}$ grade, you wanted to pass the test?) Yes, yes. (And did you find in the end?) I found a teacher that also had a disabled daughter and she knew how to work [with disabled persons] and she accepted me."

One other example was the admission problems encountered by a young visually impaired (practically blind) that remembers: "...when I said I wanted to be accepted in the 
college, they said "No, it's not possible." (Who?) First, at the acceptance commission, the girls were in shock and said, "Well, it can't be done." "Why?" "Well, you can't see." "So what?" After that, they sent me to the dean. He tried to give me a hint that maybe I could drop it and I gave him a hint that maybe I would not and then he sent me to some kind of a medical commission that would then be assembled for the disabled students. I had to look for it one whole day. (Did they have a special commission for the disabled students?) Yes, they assemble [such a] commission and at one point, when I reached the student clinic in the Complex, we were lost and we asked the nurses on the hallway and they asked "What are you doing here?" and we answered. "Who sent you?" "The dean" "Well, tell the dean that the commission has been terminated 5 years ago." It's oh so great, very cool. I called the dean and told him "Dean, that's actually not possible!" So he said "Ok, then let's think of something else. Go bring me 2 certificates from the ophthalmologist and one from the psychologist indicating that you are fit." "Fit for what?" "Just go and bring them to me!" Ok, alright. And then, I went to the County Hospital and entered the psychologist's office, the psychiatrist's, actually, not the psychologist's, so the psychiatrist looked at me, asked me 2 questions, saw that I was totally ok, I talked, I joked, I was in no way mentally impaired, and he gave me that certificate. I went to the ophthalmologist and the lady took out a....I don't know what that was...umm ... a big book of something, went through it and asked me "What's you left eye sight?" "None." "And the right eye?" "None." "You're not fit!" "Why am I not fit?" And then I kind of snapped and told the lady doctor I'd take her by the neck and she said "I'll give you the certificate but it would not be my responsibility." I said that was ok and that she should give it to me and I left. I really didn't have the patience to sit there and tell her I had read until then more than she had ever read and then she gave me the certificate and the dean had no other choice than to accept me in college, again, on my own responsibility. So the absurd thing was that in the law school, in an institution where...that provides people that are in charge with the law to be discriminated from the beginning".

After gathering such testimonies, in the next phase, we discussed with representatives of the school system and some school administrators trying to catch their perspective on this issue and some possible explanations for the dysfunctions signalled by our disabled subjects.

What could be noticed as a general characteristic of all interviews is that the former "medical" model present in the communist regime with the segregated schools based on the "pedagogy of defectology" is much more nuanced nowadays even if it is not totally abandoned. The approach used by most of our respondents is more somehow oriented toward the "inclusive school" model. But still the common attitude is more about "educational needs" and "experts" intervention" and not at all about "human rights" and "citizenship".

Also we found that teachers, administrators and other categories of experts are sometimes very critical about the system and the official policy and they are not at all obedient executors of the government's rules and decisions. This could be an effect of the interview subject situation, but we found them truly concerned and genuinely disposed to take position in favour of their students in unfair situations in the humanistic spirit of "social justice".

As we mentioned already, in the former communist regime the "defectology" pedagogy was dominant: mainstream education was intended for "normal" able body students and the disabled ones had to be enlisted in segregated "special schools" organized on the disability type criteria. The reason was "special educational needs" and the staff in these segregated schools was specially trained to deal with these needs. Almost all the conditions were different: the curricula, the teaching methods and materials, the class organization (reduced number of students and teaching time, increased duration of brakes and many others). Also the "rights" of the partners of the educational process were different - "rights" 
meaning the material benefits one is entitled to - the salaries of the staff were $15 \%$ higher than in mainstream education and students received free meals, free accommodation and free equipment's. The reverse of this needs' assistance perspective was the total exclusion of the disabled people from the society. Their special education was designed to train them toward specific vocational careers and after graduation to employ them in special protected units, so that their contacts with the mainstream society were almost absent.

After the dissolution of the communist regime came also the dissolution of this wellorganized (but segregated) special education. Under the pressure of the parents but also because of the international opening of the Romanian society new models appeared in the education system. After the 1990's the new model became "the inclusive school" meaning the integration of the students with "special educational needs" in the mainstream education. It has been a difficult process, consuming a lot of efforts, time and money but the results were discouraging. Very few disabled students succeeded to be integrated in the general education and these happy cases happened in the prestige schools with dedicated teachers and mainly because of the huge efforts of the parents. The most part of the disabled students had to address the old special schools (much less organized and financed than they used to be) to get vocational training for the special protected units that disappeared in the meantime.

But let's get to the informants' stories. One social sciences teacher highly graded $(\mathrm{PhD}$ in Sociology) and former scholar inspector tells us: "I think it's very stupid to dissolve the special education (because there have been some attempts...). And this because of financial pressures because the costs are too big. And then there is an inclusion trial. But there are children that cannot be ever included. If we take the alternative of equal access to the education for everybody we have to go in the west and to have private education. But here the dissolution of the special education is a crime. What can we do with a child in the fifth grade with an IQ of 30? What to do with him if the education is mandatory? "

This teacher is in fact signalling some important challenges of the inclusion education initiatives in Romania. As we mentioned earlier "inclusive school" is present since more than 15 years in the programmatic documents of the educational system and the idea became more pregnant after 2007 since Romania is member of the EU. But the concept cannot cover all situations and it has not to be implemented in an exclusivist manner. It's true that it have been some pressures to close the special education units in favour of the inclusive schools for a number of reasons. The teachers there are highly trained and the schools have an exceptional number of experts employed (psychologists, speech therapists, social workers, educators, kinetics-therapists, and many others). They are working fewer hours than in mainstream schools and are better paid (15\% more).

All these and the students' exceptional benefits (free meals, accommodation and equipment's) have increased the cost for this special education while the general education budget is diminishing because of financial constraints. There were also some rumours about poor parents applying for the special education facilities for their not quite disabled children!

In fact the special schools are maintained in Romania and for diminishing the stigma associated with these segregated educational units they are now called "Centres for Inclusive Education" but in fact their inclusive activities reside mainly I the fact that children are no longer staying home. They are brought to these schools and they can socialize with other disabled children like them but they still remain excluded from the mainstream society and education system.

Another big challenge is about the diploma the special schools provide to their disabled graduates. For a long period when the vocational schools were also popular in the mainstream education, the graduation certificates from the special schools were the same as those from the mainstream vocational school attesting vocational abilities that were enough 
similar. But after the dissolution of the vocational system in the mainstream education, almost all the students go for theoretical high school studies (even if only two thirds of them pass their baccalaureate). So the special schools graduate certificate is not at all similar with others diplomas and do not permit any further inclusion in the education or labour market.

Speaking about access in primary education for disabled children, another teacher from a mainstream high school, but having also experience in special education, told us: "In the primary education the teacher is very important. If he/she accepts... For instance I know from my kid that in his class is a little girl with sensorial deficiencies. Of course with prosthesis (audio) and she graduated with all her colleagues. The teacher was much implicated and she made us, the parents, to accept this because parents opinion is very important, I can tell you from my experience. When there were problems with a child, the others' parents came to school and protested that he disturbed the class. But I can tell you that in 8 out of 10 cases the parents are set by the teacher. So there are not the parents that don't accept, the teacher doesn't accept. And then the scholar inspectorate commission orient the child to another school. When I worked as inspector I found another school where the child felt accepted. I knew some brave teachers who were very open! This was very important for the child to feel accepted..."

It looks very clear that the teachers and school administrators have the possibility to accept or deny the students access in the classroom. And there are procedures that assist them in this respect. So, if the school administrators and the parents cannot find a solution by transferring the child in another class or in another school, the parent is oriented to ask help from other scholar authority. In fact, if there is a referral about a maladaptation to the school requirements from a child, the case is taken by the CJRAE (County Centre for Resources and Educational Assistance).

This centre has a special commission made of professionals (psychologist, social worker, and physician) and also the headmasters from the special schools in the county. They are evaluating the case (at least the file of the youngster) and take a decision, usually by orienting him/her to the proper special school (or toward the special school with more free places). Usually the parents are involved in the process and there are situations when they don't want their children to be sent to a special school. Our informants told us that this is not mainly because of stigma associated with these special schools but because of the fact that the handicap allowance of the children should be given to the special boarding school!

If the parent is not willing to enlist his child to the special school then he can keep him/her home and ask for itinerant support teacher. They are delivering home education with each child but no so many hours. In fact their weekly norm is 16 hours and they usually have 8-10 children so they do at most 2 hours per week with each student, the progresses being very difficult. But usually in these cases one can find mainly children with severe mental retardation that parents cannot afford to send to any institution.

So the access to the school may be blocked by the school itself, if teachers are not able or not willing to make special efforts with a child. Some prestigious schools have also other ways to accept only the best performer students. One teacher from such a prestigious school told us:

"First of all, education legislation is the one that block the access to high-school " $X$ ". Because if we analyses the way one could arrive in this school it is clear that it's about average. The average in the last four years (grades 5-8) and the national evaluation. It is clear: we had the last admission average 9.20 (out of 10). And this was the weakest result so you can see that the level of the requirements is very high. So it's clear that a student with disabilities from the mainstream education with or without support structures didn't have the possibility to reach this level. So, it is not the school who denies the access of these students, 
the school is open. We don't have such problems, you can see from the voluntary activities we organize. The school is open to inclusion, integration and so on... The problem is legislation."

The teacher has his point here, we will come back about this competitive education later, but this performance-based admission process is undoubtedly a barrier at least for the intellectual disability students.

If these barriers are active, there are also good initiatives and clear pathways toward inclusive education. Another informant, director of a vocational high school, told us about an interesting experiment: "We were the first school in Romania that proposed the integration of a number of classes of special education in our mainstream education vocational school in 1993. We continued this project for 15 years and children with intellectual disabilities had achieved vocational training for professions that we used to offer: tailoring, shoe-making and mechanic - assistants for textile industry. There were many classes, once we had 10 parallel classes, more than 250 students with disabilities each year. The teaching staff was our normal staff but they have had some special trainings for working with special educational needs. Their curricula was adapted: they had more practical activities and less theory classes. The practical abilities for real work were more important and we succeeded to orient them toward profile factories which employed most of them". Unfortunately, six years ago the project stopped, these classes returned to the special education units that were considered as more experienced for them.

\section{Competitiveness perspective: schools like enterprises are competition oriented and disabled students cannot play their role}

As we observed earlier an important barrier of the access of the disabled students in the mainstream education is represented by the competitiveness perspective in the admission process, the most important criteria being the average of the grades from the former 4 years and the results in the national evaluations. In fact the whole functioning of our education system is based on competition and this is not a new perspective. Even in the communist regime, the best schools were intended for the best achieving students and rewards for those having the best results started since kindergarten. All the admission processes after the mandatory education of 8 grades, in high schools and universities, were big contests with winners and losers and parents spent a lot of efforts and money to help their children to win these exams. Teachers were also evaluated on the base of competition and evaluated on the base of the results of their students in ordinary evaluations, admission exams or in the national Olympic contests. In fact competitiveness in schools is part of the education system role, to prepare for the future competition in economy and society as a whole.

But there is a difference between the former communist and the actual regime in Romania. The former society was very much centralized and directed by the communist authorities while nowadays the state has retired from his former functions, the society being much more market oriented and following a "neo-liberal" ideology even in the redistribution of benefits as shows some east European sociologists (Mladenov, T. - 2015).

Coming back to educational system one can ask what are its targets and objectives regarding the disability students. What type of education they get and for what purpose? An inclusive school would be fit for an inclusive society but when the labour market and society as a whole is excluding this category the segregated education seem the proper approach and illustrate the reproductive efforts of the society through the education in the Bourdieu perspective.

But let's go back to our informants. Speaking about disability students' chances in the 
educational system a high school teacher told us: "It depends much of the disability. If we speak about a student with motor disability he is almost equal with a student without disabilities but if we speak about a student with limited intellect it's clear that he cannot reach the same level. He has an adapted curricula, has a lot of adapted activities and so on, but it is clear that he cannot reach the required level for a prestigious school where admission is based on results. Speaking about sensorial disability we have in the county deaf students. They are very well integrated in the art high school and there are many of them about 7 or 8, maybe 10 in that school. Those with mental disability are following Step by Step, or other educational alternatives, they are not left aside, there is a concern and a strategy... But unfortunately, and now I speak from the perspective of the scholar inspector for special education that I was for 8 years, the policies were limited to some financed projects and that was all!"

So it's very clear that the educational system is based on competitiveness and this fact it's a barrier, especially for the intellectual disability, in the access or in the evolution of the disabled students in the mainstream schools.

We have also the academic perspective about education competitiveness which make almost impossible the inclusion of disabled students in mainstream schools. A university associate professor, working in a special psycho-pedagogy department told us: "Since 1995, if I am not mistaken, it began the inclusion experiment and Timisoara was one of the four centres where this process started and was successful. There were pilot schools were integration was implemented and, at the end of $90^{\text {th }}$ and beginning of 2000, many schools wanted to be more and more inclusive because they were considered elite schools. Nowadays there is the reverse: schools try to become less and less inclusive because they want to be schools of excellence where students with disabilities don't find their places..."

A more radical position has a former official in the former National Agency for People with Handicap, a person with disabilities: "The problem is linked with the fact that Romania is not that open country as officials are declaring it is at TV channels and in international conferences. In reality it is a country very little open to vulnerable groups and this is to be observed in the educational system which is mainly for smart, white guys that will become Olympics. The others don't count. There is a complete meritocracy for some few Olympics that anyhow leave the country because we don't have any university in the first 100 and I don't think we shall have one soon. And then "middle-class" in the educational system do not exist. There are many cases when the parents went to educators, headmasters and teachers and make pressures to get off the classes those children that keep the class level low and teachers cannot focus exclusively toward children who wants to become elites..."

This is an exacerbated position, no doubt, and it is specific to the activist fight for rights for people with disabilities, but one cannot deny that there is an important reality hidden under this bitter statement.

In fact, this competition based education is a real challenge for the inclusive school perspective, and for the most Romanians this is the major factor for segregated school system. Let's see how European Union solves this problem!

Personalised learning is a European Union policy aim. Strategic Objective 3 of the strategic framework for European co-operation in education and training (ET 2020): Promoting equity, social cohesion and citizenship states: 'Education and training systems should aim to ensure that all learners - including those from disadvantaged backgrounds, those with special needs and migrants - complete their education, including, where appropriate, through second-chance education and the provision of more personalised learning.'

Significant challenges remain to be addressed in the area of equity, diversity and the 
promotion of fundamental values. Europe needs more inclusive and equitable education systems that enable all citizens to succeed in education and to develop their full potential, irrespectively of their background and according to their specific learning needs. The challenge is to create inclusive learning environments where disadvantaged learners receive the support they need to succeed and feel respected and valued. Our education systems need to actively seek to promote justice, tolerance, solidarity, intercultural understanding, active citizenship, respect for diversity and fundamental rights - values and attitudes which are just as fundamental for the cohesion, success and well-being of our societies and can be best promoted through education and training.

\section{Education for citizenship?}

It is clear that many Romanian teachers especially in secondary education do not feel comfortable to work with disabled students. They pretend that they don't have expertise, or that they are not prepared to work with this category and it would be more profitable even for these students if they would be educated by a specially trained personnel in a specialized environment. Some others claim the low payments in education and the efforts they have to make to teach so many students and to make them respond to the requirements. It is why they don't have time and possibility to adapt the curricula or the teaching methods to the special education needs of some students. So they decline the inclusion school concept in favour of "excellence" school concept. It is not always the case for kindergartens or primary school teachers who are more open to working with special students in mainstream environment.

This is probably because of their training (that used to be done in pedagogy high schools and now in universities in pedagogy departments) which is more oriented toward psychology or special pedagogy and which discuss more about deficiencies. The other teachers working in secondary education, have less contact with psychology and pedagogy being specialized in "earth sciences" or even "humanistic sciences" but not "social sciences" and this could be an explanation of their reticence. As one of our teacher subjects told us: "Why have I to take care of these children? I have a curricula to respect and I have to teach it. I have a scholar inspector who comes and check if I am doing it right. So don't ask me to adapt the curricula because I don't know how..."

And not only teachers are reticent to the inclusion process but also headmasters, the school managers. Their motivation is a little different and is linked with the new functioning of the schools in Romania in the demographic and financial crisis conditions. The danger of losing students and disappearance determines a new scholar policy and a new marketing activity, more aggressive, trying to create an image of high status, very effective and very good results school.

The presence of disabled students in this «prestigious school» is considered a burden that would demotivate the parents of «normal children» to enlist there. So that the school management is looking for ways of avoiding the admission of disability students in their institution. It is also true that the process is nowadays more nuanced. It is not legal to discriminate in Romania, so that it is more advisable to admit the school incompetence to educate this type of students and to predict future troubles in their graduation and to recommend the parents to look for special schools as being more satisfactory for their educational needs. One of our informants who is director of a County Centre of Educational Resources and Assistance told us: "It happens that some of the school directors to tell "we cannot receive you". It is a discrimination that could be punished by the National Council against Discrimination. So I explained them that there is a difference between saying "we don't know how to do this, we don't have the right resources, maybe it would be better for you 
to try in another school because we don't do this right" and "in any case you cannot come here with this child."

In fact teachers are the main opponents for special needs children's inclusion in mainstream schools. It's true that they are not very well paid and therefore not very open to many efforts and changes of their traditional way of teaching in the sense of adapting the curricula to the specific needs of their students.

But there are also other ideas that teachers have, being a prejudice against disabled students' inclusion, ideas referring to the equality of treatment for all children like a basis for the equality of rights of the citizens in a democratic society. The same informant gave us an example of such a teacher that "observe the justice" in grading his students: "For example we have a child that benefits of curricular adaptation and itinerant support teacher, but the classroom teacher do not accept to grade him with more than 5 (out of 10) even if the adapted evaluation result should be graded with 9.5 (out of 10). He doesn't understand that the child's grade should evaluate his progress and should not be compared with the results of the other children in the class."

We also had other testimonies from our informants in the previous phase of our research telling that some university teachers refuse to offer the electronic support of their courses to a blind student motivating that nobody receive it and this means a real equality of treatment and democratic attitude.

There are also instances where teachers blame the parents for not staying long enough with their disabled children, for not knowing how to respond to their needs and not cooperating with the teachers well enough, or even for having unrealistic expectances for their special needs children. Look what a well-intended and experienced informer told us about the parents: "I think that the big problem is not ours (the teachers) or of the children, but belongs to the most part to the parents. We have some ideas about disabled people from classes, conferences or workshops..., but parents are very few to know the problems that their disabled children are confronted with in a mainstream school. That's why they come to 7 years. They need 7 years of home education, and the parents are modelling the child's education, teach him certain things and requirements. Those with special needs are not prepared to enter the "normal" education."

In fact here lies a very tricky perspective about equality and democratic education. The real equality of chances in the case of people with disabilities means inequality of treatment because the possibilities of the beneficiaries are very unequal with the others, people without disabilities.

Let's come back to the origin of the term handicap: "a race or other contest in which certain advantages or disadvantages of weight, distance, time, etc., are placed upon competitors to equalize their chances of winning."(http://dictionary.reference.com/browse/handicap)

So handicap means in fact etymologically positive discrimination! But what about inclusion, is our school oriented to inclusion of special needs students in mainstream schools? Obviously not! And this is not a specific problem of the Romanian education system. As Michel Oliver describes in a very well written book, (2006)in United Kingdom, one of the decisive issues in the education of disabled children in the years 70' from 90' was the integration in the mainstream schools. The report written by Lady Warnock, published in 1978, and the Education Act from 1981 both supported the principle of integration but didn't add much to the rights as citizens for disabled children. The Education Reform Act from 1988 was to be the vehicle of bringing the discipline of the market into the process of schooling and the practice of teaching. The Government introduced the "national curriculum" in order that 
schools and teachers can do what they like as long as, at the end of the day, the national curriculum is delivered.

The Act and the regulations derived from it allowed for the modification and disapplication of the national curriculum for disabled children in certain situations and under certain conditions at the discretion of the head teacher. The changes required from the schools in order to accommodate children with special needs relate to the establishment of special needs department, the provision of support services both internal and external to the school. As teachers are concerned, they need to acquire extra knowledge and different skills in order to facilitate the process of integration.

So this was about 20 years ago, the situation of the integration of special needs students in the mainstream educational system in United Kingdom. It looks similar with the Romanian integrative policy into the educational system. It could represent a model for our legislators and the educational authorities could promote this strategy (as they sometime even do), asking for resources to develop a non-segregated education system.

The problem is that this integrative model is not very much accepted by the disabled people themselves. This "old view" of integration is dominated by the notion of "normality" and requires the acceptance and tolerance of children with special needs. People, teachers and children are encouraged and educated to acceptance and tolerance of those who differs from this "normality". It's about personal tragedy theory and deficit theory in educational terms.

Tragedies and deficits are unfortunate and these poor individuals should not be made to suffer further through rejection and stigmatization: they should be accepted and tolerated. This discourse sound very familiar in Romania and usually belongs to the educated and modern-oriented professionals and politicians. Unfortunately this is not it and it looks that we are only at half-way (or approaching it). Because why to include disabled people into education if society is excluding them, and the most exclusive factor is the labour market. As one of our informants observed: "I don't believe we are prepared as society. Maybe as educational system we make an effort and integrate them but as society I don't know if we are prepared. If we look at the society, I don't know if an adult is prepared to collaborate or to work with a disabled person. It can be observed a certain marginalization, even if not direct, it's not said openly, but there are reticent people when they have to relate to people with disabilities. For children is even more difficult being rejected by other kids and adults, because they are more sensitive".

One of the function of education is to assure the integration of individuals into society. The purpose of the schools is to educate all children, and not only those who met the increasingly narrow band of selection criteria. The special schools even full of educational resources, have failed to empower the disabled children to look for their right place into society. This failure to empower is not tolerated any more by disabled people themselves, struggling to confront the processes that excludes and segregate them: "Increasingly we disabled people are raising our voices to speak against warehousing of disabled people in special institutions and against the denial of basic equal and civil rights. We no longer accept segregation and paternalism from people like medical experts, policy makers and administrative officials. (European Network of Independent Living - 1989).

In this perspective the new function of education in the case of special needs students should change from integration to inclusion. "What is needed is a moral commitment to the integration of all children into a single education system as part of a wider commitment to the integration of disabled people into society" says Michael Oliver (1996). "The history of the twentieth century for disabled people has been one of exclusion. The twenty-one century will be struggle for inclusion. In this struggle special, segregated education has no role to play" 
So, our educational system, its organization and administrators have still long way to go to find the inclusive perspective, very present in the contemporary developed countries. Even if some measures appeared and some steps have been made, inclusion remains an important, but still faraway requirement of our school and society.

\section{Conclusions:}

- There are important barriers in admission of the disabled students in mainstream schools (at all levels but increasing as the education level increases). The most important enemies of the inclusion of disabled students into general educations are the teachers that reclaim lack of resources and special training and also a big number of students in the class, that decrease the possibility of individualized activities with students.

- Another factor incriminated is competitiveness perspective: schools like enterprises are competition oriented and disabled students cannot play their role. Competition and averages are the bases of admission in secondary schools, high schools and universities and the special schools are not entering the competition.

- The perspective of human rights (disabled children have rights to education) is replaced by the perspective of special rights (disabled children have rights to special and segregated education made by experts - specialists). The society as a whole is discriminating the disabled citizens and mainly the labour market, so that inclusive school would not fit very well in a segregated society.

In fact the "inclusive education" European model seems still far for the Romanian educational system. Even the objective is clear the path is still unclear, due the discriminatory resistance of the society. A learning process is needed but the process seems difficult because students refuse to learn and teachers are hard to find. 


\section{REFERENCES}

Bourdieu,Pierre Jean Claude Passeron, (1990) Reproduction in Education, Society and Culture, Sage Publications Inc,

Fink, D., 2008. The road to transformation in education - Learning, leading and living systems, online conference paper http://www.cybertext.net.au/inet_s4wk1/p4_18.htm

Council of the European Union, 2010. Council conclusions on the social dimension of education and training. 3013th EDUCATION, YOUTH AND CULTURE Council meeting Brussels, 11 May 2010. http://www.consilium.europa.eu/uedocs/cms_Data/docs/pressdata/en/educ/1143 74.pdf

European Commission, 2010. Communication from the Commission to the European Parliament, the Council, the European Economic and Social Committee and the Committee of the Regions. European Disability Strategy 2010-2020: A Renewed Commitment to a Barrier-Free Europe. /* COM/2010/0636 final */

Council of the European Union, 2009. Council Conclusions of 12 May 2009 on a strategic framework for European cooperation in education and training (ET 2020) Official Journal of the European Union, C $119,28.5 .2009,2-10$

United Nations Educational, Scientific and Cultural Organization (UNESCO 1994) The Salamanca Statement and Framework for Action on Special Needs Education, Paris.

European Agency for Development in Special Needs Education, 2011. Mapping the Implementation of Policy for Inclusive Education: An exploration of challenges and opportunities for developing indicators. Odense, Denmark.

European Agency for Development in Special Needs Education, 2012. Raising Achievement for All Learners Quality in Inclusive Education, Odense, Denmark

Organisation for Economic Co-operation and Development, 2011. PISA in focus 2011/2 (March) Improving Performance - Leading from the Bottom. Paris: OECD

European Agency for Development in Special Needs Education, 2012d. Raising Achievement for All Learners Quality in Inclusive Education. Odense, Denmark: European Agency for Development in Special Needs Education. $\quad$ http://www.european-agency.org/publications/ereports/ra4al-synthesisreport/RA4ALsynthesis-report.pdf

Bennett, S. and Gallagher, T.L., 2012. The Delivery of Education Services for Students who have an Intellectual Disability in the Province of Ontario. Toronto: Community Living Ontario

European Agency for Development in Special Needs Education, 2012a. Young Views on Inclusive Education. Odense, Denmark: European Agency for Development in Special Needs Education. http://www.europeanagency.org/publications/ereports/young-views-on-inclusiveeducation/YoungViews-2012EN.pdf

Mladenov, T. (2015). Neoliberalism, Post socialism, Disability, Disability\& Society, 30:3, 445-459, DOI: 10.1080/09687599.2015.1021758.

Council of the European Union, 2010. Council conclusions on the social dimension of education and training. 3013th EDUCATION, YOUTH AND CULTURE Council meeting Brussels, 11 May 2010. http://www.consilium.europa.eu/uedocs/cms_Data/docs/pressdata/en/educ/1143 74.pdf

Organization for Economic Co-operation and Development, 2007. No more failures: Ten steps to equity in education. Paris: OECD

Leadbeater, C., 2005. The shape of things to come: personalised learning through collaboration. London: DfES NCSL

Hargreaves, D., 2006. A new shape for schooling? London: Specialist Schools and Academies Trust Oliver, Michael - Understanding Disability - From Theory to Practice, 1996, St. Martin's Press, New York. 